\title{
INTRODUCTION TO THE SYMPOSIUM ON CONTEMPORARY BANKING RESEARCH: THE USE OF FIXED EFFECTS TO DISENTANGLE LOAN DEMAND FROM LOAN SUPPLY
}

\author{
Sanja Jakovljević, Hans Degryse, and Steven Ongena*
}

With the onset of the financial crisis, disentangling the effects of loan demand and supply in contemporary banking research has become vital for a proper assessment of supply-related banking shocks. These shocks may negatively affect the real economy through many channels, such as the lending channel of monetary policy transmission, the bank risk-taking channel or the evaluation of macroprudential policy efficiency. All these rely on separating the two lending components. Empirical identification has largely relied on the use of demand-related fixed effects, which has also been applied in several analyses within this Symposium. ${ }^{1}$ Morales-Acevedo and Ongena ("Fear, Anger and Credit. On Bank Robberies and Loan Conditions") apply such a control for loan demand at the industry level in order to assess the impact of bank branch robberies in Colombia on subsequently approved loans and their conditions, conjecturing that such a stressful event experienced by loan officers leads to temporarily emotionally-motivated lending decisions. Agarwal et al. ("Commodity Prices and Bank Lending") use this method to establish how reductions of commodity prices affect lending in developing countries, or more specifically, which bank characteristics lead to a stronger transmission of the global price shock through loan supply. Their investigation is based on loan application data for Uganda.

The application of firm fixed effects specifically as a control for unobserved firm heterogeneity assigned to loan demand has been pioneered in the work of Gan (2007) and Khwaja and Mian (2008). This approach requires information on bank-firm exposures and relies on firms that borrow from at least two banks. Otherwise, firm demand would be misspecified in a regression of the following form:

$$
\Delta L_{b f}=\alpha_{f}+\beta_{b}+\varepsilon_{b f}
$$

where $\Delta L_{b f}$ denotes loan growth at the bank-firm level, while $\alpha_{f}$ and $\beta_{b}$ are firm and bank fixed effects serving as proxies for loan demand and supply, respectively. The error term is denoted by $\varepsilon_{b f}$.

The equation above has first been applied in contexts where an exogenous shock affects loan supply, hence the empirical setup corresponds to a difference in differences approach comparing pre- and

\footnotetext{
* Corresponding author: s.jakovljevic@lancaster.ac.uk. The authors are at Lancaster University; KU Leuven and CEPR; and the University of Zürich, SFI, KU Leuven and CEPR, respectively. The Symposium on Contemporary Banking Research was edited by Steven Ongena and Wes Wilson. We thank Wes Wilson for valuable comments on this introductory paper. Ongena acknowledges financial support from ERC ADG 2016 - GA 740272 lending.

${ }^{1}$ Our note focuses on those papers of the Symposium that apply fixed effects specifically to separate loan demand from loan supply. Several other papers use fixed effects that account for (un)observable determinants affecting the main relationship under analysis in a cross-country bank-level empirical setting. Fatica et al. ("Banks, Debt and Risk: Assessing the Spillovers of Corporate Taxes") apply bank-group, year and country-year fixed effects in their assessment of the impact of corporate tax reforms on debt and equity choices. Qi et al. in this Symposium ("The Travels of a Bank Deposit in Turbulent Times: The Importance of Deposit Insurance Design for Cross-Border Deposits") use country-pair and year fixed effects when estimating the effect of deposit insurance on bilateral cross-border deposits. Based on data from a single retail bank, Brown et al. ("Numeracy and On-the-Job Performance: Evidence from Loan Officers") include branch and time fixed effects when accounting for numeracy differentials across loan officers.
} 
post-shock changes in lending. Gan (2007) studied how a decrease in asset prices affected loan supply due to real estate exposures of banks in Japan. Khwaja and Mian (2008) explored the effect of unannounced nuclear tests in Pakistan, which affected liquidity of banks due to reductions of their dollar-denominated deposits. In such a case, the loan demand control is not necessarily time-varying. As more granular datasets became available (e.g., proprietary credit registers of central banks), the time dimension was added to the analysis of lending shocks, hence firm-time fixed effects were used:

$$
\Delta L_{b f t}=\alpha_{f t}+\beta_{b t}+\varepsilon_{b f t}
$$

where the term $\Delta L_{b f t}$ denotes loan growth at the bank-firm-time level, while firm-time and bank-time fixed effects are represented by $\alpha_{f t}$ and $\beta_{b t}$, respectively. The error term is $\varepsilon_{b f t}$. One example of the use of such an approach is Jiménez et al. (2012), who analyse the strength of the monetary policy transmission mechanism through the restrictive effect of higher short-term monetary policy rates on loan supply.

An additional benefit of using highly-disaggregated bank-firm data, besides incorporating loan supply and demand controls in form of bank-time and firm-time fixed effects, is also to account for endogenous matching of banks and firms (i.e., bank-firm fixed effects). Examples of such an approach can be found in Paligorova and Santos (2017) or Altavilla et al. (2018). The estimation procedure in that case translates into the following equation:

$$
\Delta L_{b f t}=\alpha_{f t}+\beta_{b t}+\gamma_{b f}+\varepsilon_{b f t}
$$

Compared to Equation 2, the additional explanatory variable are bank-firm fixed effects $\gamma_{b f}$, used to control for any unobservable bank-firm heterogeneity. While the use of multiple-bank firms is a prerequisite for the application of the estimation procedure described above, the question arises whether such an empirical setup suits either the sample, or the context under analysis. As Altavilla et al. (2018) show, using a harmonised collection of credit registers from several EU countries, the share of firms with more than one borrowing relationship in the total number of firms may vary between $10 \%$ and $46 \%$. At the same time, the share of such firms in total borrowing is relatively higher, between $41 \%$ and $87 \%$, as larger firms typically borrow more and from several banks. However, these percentages point to the possibility that the methodology above might not apply to a significant proportion of firms and does not capture the entirety of the lending portfolio of banks. Keeping in mind that single-bank firms might differ from multiple-bank firms, especially in terms of age or size, it is not clear whether the implications of the lending channel have similar (or identical) effects on the real outcomes for these firms. Furthermore, regulators might be particularly interested in the small firms that may be dropped from the analysis when relying upon multiple-bank firms.

Degryse et al. (2019) introduce and verify a novel method that incorporates single-bank firms into the analysis of the effects of supply shocks on borrowing firms. In their sample of firms incorporated in Belgium, the authors establish that $84 \%$ of firm-time observations belong to firms that do not have multiple-bank relationships, representing $46 \%$ of the lending portfolio of banks. They also find that single-bank firms are systematically different from multiple-bank firms. Firms with just one borrowing relationship are on average younger, smaller (in terms of total assets and the number of employees), have more tangible assets and borrow smaller loan amounts. Based on these findings, the authors explore an alternative to a firm-level demand control: firms are clustered into industry-location-size bins, under the assumption that such similar firms have identical loan demand. Therefore, firm-time 
(FT) fixed effects can be replaced by industry-location-size-time (ILST) fixed effects, and would incorporate almost the entire sample of bank-firm relationships. Equation 2 above then becomes:

$$
\Delta L_{b f t}=\alpha_{I L S t}+\beta_{b t}+\varepsilon_{b f t}
$$

i.e., firm-time fixed effects $\left(\alpha_{f t}\right)$ have been replaced by industry-location-size-time fixed effects $\left(\alpha_{I L S t}\right)$, while the dependent variable (loan growth; $\Delta L_{b f t}$ ) remains defined at the bank-firm level. To verify whether such an alternative demand control is viable, in the first step the authors compare how the inclusion of ILST effects instead of FT effects works in the sample of multiple-bank firms. Based on results from Equations 2 and 4, the estimated supply shocks $\left(\hat{\beta}_{F T}\right.$ and $\left.\hat{\beta}_{I L S T}\right)$ are compared. If the alternative demand control has led to misspecification, the two supply shock estimates will vary substantially. However, the estimates are highly correlated.

In the second step, the authors include single-bank firms into the analysis. As the two demand controls can be assumed to be very similar (as verified in the first step), the difference in the two supply shock estimates can be attributed to variation in supply shocks faced by multiple-bank firms and single-bank firms. Indeed, the month-by-month correlation between $\hat{\beta}_{F T}$ from the first step and $\hat{\beta}_{I L S T}$ from the second step varies significantly, in the range between 0.23 and 0.94 . This finding indicates that the exclusion of single-bank firms from the analysis of supply-related shocks might lead to biased estimates of the strength of such shocks, but also of their real effects. The authors corroborate such a conclusion by showing that the negative effects of loan supply shocks on growth in financial debt, total assets, fixed assets and operating margin of firms are only properly identified with supply shocks estimated using both single- and multiple-bank firms.

Other firm characteristics (age, riskiness, availability of internal resources) have been considered in the creation of the alternative demand control, but the loan supply estimates obtained with the combination of industry affiliation, location and size as a demand control have exhibited most similarity with the standard bank-time fixed effects. It is also encouraging that such readily available firm features showed most relevance, as this might enable other researchers to apply such an approach. On the other hand, finer and more detailed clustering of firms might saturate the specification and lead to losses in the number of observations, hence it should only be applied if it does not disable appropriate disentanglement between loan demand and supply.

While Degryse et al. (2019) show more formally that firm fixed effects may be substituted with alternative loan demand controls using a clustering procedure, other papers have proceeded with a direct application of such an approach in their empirical analyses. De Jonghe et al. (2019) use identical industry-location-size clustering to show that less risky firms or firms operating in sectors in which their borrowing bank is more present or specialized are better shielded from banks' funding shocks. Acharya et al. $(2018 ; 2019)$ cluster firms according to their country of incorporation, industry affiliation and credit quality rating to assess the real effects of the sovereign debt crisis and of the subsequent unconventional monetary policy measure in form of the Outright Monetary Transactions (OMT) program. In this Symposium, Agarwal et al. (2019) cluster firms in the same district and industry. Morales-Acevedo and Ongena (2019), combine firm size, age, number of borrowing relationships, existence of prior arrears, credit quality rating and industry affiliation to form firm clusters.

The empirical literature also offers other improvements to the well-established use of firm fixed effects. Amiti and Weinstein (2018) argue that an equilibrium condition should be respected when demand and supply shocks are estimated: demand equals supply, hence no increase/decrease in 
demand can result in an observable bank-firm relationship without a corresponding increase/decrease in supply, and vice versa. The relevance of one lending component for the other is captured using weights: in the universe of bank-firm relationships, how relevant is any firm in the lending portfolio of a bank, and how important is any bank in the borrowing portfolio of a firm? Tielens and Van Hove (2017) formally show that the application of these adding-up constraints in an empirical setup with multiple-bank firms is equivalent to using a weighted least squares procedure, with the relevance of each firm for a given bank as the weight.

While the use of firm(-time) fixed effects or alternative demand controls enables separation of loan demand and supply, it also relies on the bank-firm relationships that have already been established and can be observed. In fact, the initial step in the lending process are loan applications, which might be approved or rejected. Such information may be contained in credit registers (e.g., Agarwal et al., 2019; Jiménez et al., 2012), but it can also be found in firm-level surveys, such as the Business Environment and Enterprise Performance Survey (BEEPS) of the European Bank for Reconstruction and Development (EBRD) and the World Bank. Jiménez et al. (2014) use loan application and approval data from the Spanish credit register to analyse whether the environment of low monetary policy rates induces more risk-taking by banks. Popov and Udell (2012) rely on loan rejections from BEEPS to identify credit-constrained firms and infer the effects of bank capital shocks on borrowing firms.

As can be seen from the discussion above, highly disaggregated data may be helpful in disentangling loan supply from loan demand, but the specificity of the context under analysis might hinder researchers from making broadly applicable conclusions. Harmonisation and unification of credit registers alleviates such concerns and has been the focus of the AnaCredit project by the European Central Bank (ECB). The first empirical results are already becoming available based on the consolidated credit register of 15 European Union members (Austria, Belgium, Czech Republic, France, Germany, Ireland, Italy, Latvia, Lithuania, Malta, Portugal, Romania, Slovakia, Slovenia and Spain). Altavilla et al. (2018) rely on this data to show that ex-ante more vulnerable banks, i.e. banks with a higher share of non-performing loans, engage in risk-taking behaviour. Supply of loans to riskier firms can be reduced through centralized banking supervision under the Single Supervisory Mechanism, but this mitigation effect is evident only in stressed economies of Italy, Portugal and Spain. The risk-taking channel of monetary policy in stressed countries is also weakened due to supranational supervisory efforts. Further research using this dataset is surely under way, and will provide deeper insights into the monetary policy transmission mechanism and the effects of banking regulation and supervision.

\section{References}

Acharya, V.A., Eisert, T., Eufinger, C., Hirsch, C., 2018. Real Effects of the Sovereign Debt Crisis in Europe: Evidence from Syndicated Loans. Review of Financial Studies 31(8), 2855-2896.

Acharya, V.A., Eisert, T., Eufinger, C., Hirsch, C., 2019. Whatever It Takes: The Real Effects of Unconventional Monetary Policy. Review of Financial Studies 32(9), 3366-3411.

Agarwal, I., Duttagupta, R., Presbitero, A.F., 2019. Commodity Prices and Bank Lending. Economic Inquiry, Forthcoming.

Altavilla, C., Boucinha, M., Peydró, J.-L., Smets, F., 2018. Banking Supervision, Monetary Policy and Risk-Taking: Big Data Evidence from 15 Credit Registers. European Central Bank, Frankfurt. 
Amiti, M., Weinstein, D.E., 2018. How Much Do Idiosyncratic Bank Shocks Affect Investment? Evidence from Matched Bank-Firm Loan Data. Journal of Political Economy 126(2), 525-587.

Brown, M., Kirschenmann, K., Spycher, T., 2019. Numeracy and On-the-Job Performance: Evidence from Loan Officers. Economic Inquiry, Forthcoming.

De Jonghe, O., Dewachter, H., Mulier, K., Ongena, S., Schepens, G., 2019. Some Borrowers Are More Equal than Others: Bank Funding Shocks and Credit Reallocation. Review of Finance, Forthcoming.

Degryse, H., De Jonghe, O., Jakovljević, S., Mulier, K., Schepens, G., 2019. Identifying Credit Supply Shocks with Bank-Firm Data: Methods and Applications. Journal of Financial Intermediation, Forthcoming.

Gan, J., 2007. The Real Effects of Asset Market Bubbles: Loan- and Firm-Level Evidence of a Lending Channel. Review of Financial Studies 20(6), 1941-1973.

Jiménez, G., Ongena, S., Peydró, J.-L., Saurina, J., 2012. Credit Supply and Monetary Policy: Identifying the Bank Balance-Sheet Channel with Loan Applications. American Economic Review 102(5), 23012326.

Jiménez, G., Ongena, S., Peydró, J.-L., Saurina, J., 2014. Hazardous Times for Monetary Policy: What Do Twenty-Three Million Bank Loans Say about the Effects of Monetary Policy on Credit Risk-Taking? Econometrica 82(2), 463-505.

Khwaja, A.I., Mian, A., 2008. Tracing the Impact of Bank Liquidity Shocks: Evidence from an Emerging Market. American Economic Review 98(4), 1413-1442.

Morales-Acevedo, P., Ongena, S., 2019. Fear, Anger and Credit. On Bank Robberies and Loan Conditions. Economic Inquiry, Forthcoming.

Paligorova, T., Santos, J.A.C., 2017. Monetary Policy and Bank Risk-Taking: Evidence from the Corporate Loan Market. Journal of Financial Intermediation 30, 35-49.

Popov, A., Udell, G.F., 2012. Cross-Border Banking, Credit Access, and the Financial Crisis. Journal of International Economics 87(1), 147-161.

Tielens, J., Van Hove, J., 2017. The Amiti-Weinstein estimator: An Equivalence Result. Economics Letters 151, 19-22. 